\section{MÉG MINDIG „SOK VAN A PÁRNA ALATT” A PÉNZÜGYI TUDATOSSÁG MINTÁZATAI MAGYARORSZÁGON EGY FELMÉRÉS TÜKRÉBEN}

Stefkovics Ádám (a Századvég Alapítvány munkatársa, igazgatóhelyettes, doktorandusz az ELTE Társadalomtudományi Karán) stefkovics@szazadveg.hu

\section{ÖSSZEFOGLALÓ}

A modern piacgazdaságok sikerességének egyik fontos sarokköve az egyének pénzügyi kultúrájának és tudatosságának szintje. A 2008-as válság és a devizahitelesek ügye volt az, ami igazán ráirányította a figyelmet a fogyasztók pénzügyi magatartására. A hiányos pénzügyi ismeretekből és a nem tudatos pénzügyi döntésekből származó veszélyeket sokan felismerték, így azóta számos szereplő (például a kormány, az MNB) tesz erőfeszítéseket a pénzügyi kultúra fejlesztésére. Az elmúlt tíz év felmérései mindazonáltal továbbra is jelentős lemaradásról tanúskodnak. Jelen tanulmány a MABISZ és a Századvég közös felmérésének fontosabb eredményeit mutatja be, melynek célja a pénzügyi tudatosság egyes aspektusainak feltérképezése volt. Az eredmények rávilágítanak, hogy a befektetési potenciállal rendelkező egyének többségének pénzügyi ismeretei hiányosak, továbbra is kevesen fordulnak a kamatozó vagy másféle hozamot biztosító pénzügyi termékek felé, és kevesen „járnak nyitott szemmel” a piacon. A fiatalok körében találtunk bizakodásra okot adó jeleket, a pénzügyi kultúra fejlesztése mindazonáltal ma is kiemelt fontosságú feladat Magyarországon.

\section{SUMMARY}

One of the cornerstones of success in modern market economies is the level of financial literacy and awareness. The 2008 crisis and the case of foreign currency loans really brought the attention on the financial behaviour of the consumers. Many (e.g. the government or the MNB) recognized the risk arising from the lack of financial knowledge and awareness in financial decision-making, and already making efforts to improve financial literacy. Nevertheless, the polls of the last decade still report significant backwardness. This study introduces the most significant results of a poll conducted by MABISZ and Századvég. The poll aimed to investigate some aspects of financial awareness in Hungary. The results show significant gaps in financial knowledge among the majority of individuals that have potential for investment. Few of them turn to interest-bearing financial instruments or deal with their financial issues "eyes wide open". We saw some encouraging results among younger respondents, still, improving financial literacy is a core task in Hungary.
Kulcsszavak: pénzügyi kultúra, pénzügyi tudatosság, pénzügyi ismeretek, biztosítás Keywords: financial literacy, financial awareness, financial knowledge, insurance

JEL: A13, A14, D12, D13, D14, D18, D63, J11

DOI: $10.18530 /$ BK.2018.4.82

http://dx.doi.org/1018530/BK.2018.4.82

\section{Bevezetés}

Ha pénze nem is, pénzügyei mindenkinek vannak - tartja a közismert mondás. A pénzügyi kultúra ${ }^{1}$ és tudatosság állapota minden modern piacgazdaságon alapuló társadalomban meghatározó jelentőségű, annak fejlesztése általános érdek (Kovács L., 2015). A magas szintű pénzügyi kultúrát jellemzi, hogy az egyének birtokában vannak a pénzügyi döntéseikhez szükséges ismereteknek és információknak, és azok alapján képesek tudatos, a jövőbeni következményeket mérlegelő döntéseket meghozni. Az ilyen gazdasági döntések kedvezőek az egyének számára, és összességében stabil pénzügyi rendszert eredményeznek. A tudatos gazdasági szereplő ráadásul a váratlan makrogazdasági eseményekből fakadó sokkokat is hatékonyabban kezeli (Klapper et al., 2012). Egy gazdaság sérülékenysége tehát szoros összefüggésben áll az egyének pénzügyi tudatosságának szintjével (MNB, 2017; Bárczi-Zéman, 2015; Banai-Kolozsi, 2018). Pénzügyileg tudatos egyénekre még inkább szükség van olyan időkben, amikor a pénzügyi piacok egyre komplexebbé válnak, és maguk a gazdasági szereplők számára elérhető termékek is egyre bonyolultabbak és átláthatatlanabbak (Zsótér-Németh-Luksander, 2017).

A pénzügyi kultúra kutatása igazán kiemelt figyelmet a 2008-as gazdasági válságot követően kapott. A válság kirobbanásában ugyan vélhetőleg kisebb szerepet játszottak a gazdasági szereplők pénzügyi hiányosságai, a válság elhúzódásának azonban éppen ez volt az egyik fö oka (Kovács L., 2015). Magyarországon az eladósodott devizahitelesek ügye a bankok felelősségének kérdése mellett arra is rávilágított, milyen kockázatokat rejt magában a keresleti oldal irracionalitása (Banai-Kolozsi 2018, 139.; Béres-Huzdik, 2012).

A 2008 óta Magyarországon napvilágra került felmérések eredményei nem kifejezetten kedvezőek Magyarországra nézve. Az OECD 2012-es, 4 kontinens 14 országában végzett kutatásában a magyar válaszadók az elméleti pénzügyi ismeretekből első helyre, a gyakorlati ismereteket tekintve az utolsó előtti (13.) helyre kerültek (Atkinson-Messy, 2012). A 2015ben megismételt felmérés ráadásul romló tendenciát mutatott, mindössze a megkérdezettek felének voltak pénzügyi céljai, és csak negyedük vezetett költségvetést (Zsótér-Németh-Luksander, 2017). A Századvég saját felmérései is arról árulkodnak, hogy a magyar háztartások nagy részénél lenne befektetési potenciál, azonban továbbra is sokan óvakodnak a kamatozó megtakarítási formákat választani, az alacsony kockázatvállalási hajlandóság pedig általános. 
Az ilyen irányú vizsgálatokban külön figyelmet kapnak a fiatalabb korosztályok, hiszen egyrészt a pénzügyi tudatosságra való nevelésnek korán meg kell kezdődnie (Bokányi, 2018), másrészt a fiatalok gazdasági döntéseinek lehetnek a leghosszabb távú következményei (Hornyák, 2013). Az MNB 2006-os, 15-17 és 17-30 év közöttiek körében készült felmérésének legfontosabb eredménye az volt, hogy a fiatalok nem kifejezetten mutatnak érdeklödést a pénzügyek iránt, pénzügyi információforrásaik rendkívül limitáltak, jellemzően saját családjuktól informálódnak (MNB, 2006). Más kutatások is rávilágítottak, hogy a fiatalok elsősorban szüleiktől szerzik be információikat (Németh és mtsai., 2015), a pénzügyi szocializáció során a család kiemelten fontos szerepet tölt be (Zsóter, 2013). Az is látható, hogy ez a csoport a pénzügyi-gazdasági ismereteik szintjétől függetlenül erősen kockázatkerülő (Huzdik és mtsai., 2014). A fentiek mellett azt is fontos leszögezni, hogy a pénzügyi kultúra komoly különbségeket mutat a különböző szocio-demográfiai csoportokban (Luksander és mtsai., 2014). A magasabb pénzügyi kultúrával rendelkezők közé tartoznak a férfiak, az idősebbek, a magasabb jövedelműek, valamint azok a fiatalok, akik jövedelmének kisebb része származik a családtól.

A probléma jelentőségét a kormány is felismerte. Tavaly került elfogadásra a lakosság pénzügyi tudatosságát fejlesztő nemzeti stratégia, melynek célja a pénzügyi tudatosság fejlesztésének nemzeti alaptantervbe illesztése, a fogyasztók tudatossá tétele a pénzügyekben, többek között a hitelfelvétel, öngondoskodás terén. Emellett Magyarország a Magyar Bankszövetség kezdeményezésére, a Pénziránytű Alapítvány szakmai támogatásával először 2015-ben csatlakozott az Európai Pénzhét (European Money Week) közel harminc országot átfogó kezdeményezéséhez, amelynek célja az általános és középiskolások pénzügyi ismereteinek megalapozása, valamint egy széles körű szakmai összefogás megteremtése a pénzügyi tudatosság fejlesztésében aktív szervezetek, intézmények között.

Az ismeretek gazdagsága ellenére nincs érdemi javulás a pénzïgyi tudatosság terén sem a fiatalok körében, sem általában.

A pénzügyi tudatosság és bizalom kérdése a biztosítások kapcsán is kiemelten fontos. A kutatási eredmények azt sugallják, hogy a biztosítókba vetett bizalmat jóval kevésbé tépázta meg a 2008-as válság, mint a bankok reputációját, vagyis a biztosítók válságállónak bizonyultak. ${ }^{2}$ Mindazonáltal a biztosítóknak is szükségük van pénzügyileg tudatos ügyfelekre. Csak egy problematikus területet említve: közismert, hogy az idősödő társadalmak komoly kihívások elé állítják a nyugdíjrendszereket és a biztosítókat egyaránt (Vaskövi, 2018). A következő évtizedekben kulcsfontosságú kérdés lesz az egyének tudatosságának változása a nyugdíjtervezés terén. Továbbá mivel a nyugdíjcélú megtakarítások időhorizontja 3-4 évtizedes is lehet, ebben a témában a változtatások hatásaival is hosszú távon kell tervezni. A MABISZ felismerte ezt a problémát, és kifejezetten a fiatalabb korosztályokat célozva tesz is erőfeszítéseket. Erre példa a Fiatal Generációs Stratégia, amely a fiatalok tájékoztatására és kritikus gondolkodásuk fejlesztésére vállalkozik.
Jelen tanulmány a Századvég és a MABISZ közös közvélemény-kutatásának fontosabb eredményeit mutatja be, mely adalékul szolgál a témában folyó szakmai vitához. A kutatás célja a pénzügyi kultúra egyes aspektusainak feltérképezése volt a felnőttkorú magyar lakosság, azon belül különösen a fiatalabb korosztályok körében. Ahogy említettem, a 2008-as válság óta számos kutatási eredmény áll rendelkezésre a hazai pénzügyi kultúrával kapcsolatban, azonban az is látható, hogy az ismeretek gazdagsága ellenére nincs érdemi javulás a pénzügyi tudatosság terén sem a fiatalok körében, sem általában. Amellett, hogy több kutató ennek okát a pénzügyi képzések hiányosságaiban látja (Németh, 2017; Luksander és mtsai., 2014), a pénzügyi kultúra hatékony fejlesztéséhez fontos megismerni a hiányosságokat.

\section{Adatok és módszer}

Az adatok a Századvég Alapítvány által a MABISZ megrendelésére készült közvélemény-kutatásból származnak. A 18 éves vagy idősebb magyarországi lakosságra nem, kor, iskolai végzettség és településtípus mentén reprezentatív mintában 1102 fő került megkérdezésre telefonos kérdezési módszerrel (CATI) 2018. április 20. és május 6. között. A mintavételből fakadó hibákat iteratív súlyozás segítségével korrigáltuk. A mintavételi módszerből fakadóan 95 százalékos valószínűséggel az elemzésben közölt adatok legfeljebb plusz-mínusz 3,1 százalékponttal térnek el attól az eredménytől, amit az ország összes felnőtt lakosának megkérdezése eredményezett volna. A kérdőívben a pénzügyi tudatosságot érintő kérdések mellett a biztosításokkal kapcsolatos általános és lakásbiztosítási fókuszú kérdések szerepeltek. Az elemzésben a leíró statisztikák mellett a pénzügyi tudatosság demográfiai hátterének feltárására egy lineáris és logisztikus regresszióanalízist alkalmaztam.

\section{Eredmények ${ }^{3}$}

\section{Pénzügyi ismeretek és tudatosság}

A pénzügyi ismeretek mérésére egy objektív és egy szubjektív indikátort alkalmaztunk. Ami az objektív ismereteket illeti, a kutatási eredmények arról tanúskodnak, hogy a magyar lakosság döntő többsége a különböző megtakarítási formák közül egyedül a lakástakarék-pénztárak esetében van tisztában azzal, hogy jár állami támogatás a megtakarításokra (69,2 százalék válaszolt így az LTP-k esetében, 1 . ábra). ${ }^{4}$ Ugyanez az arány a nyugdíjbiztosításoknál már csak 43,9 százalék, az állampapíroknál 42,8. Érdekes, hogy az önkéntes nyugdíjpénztárakban tartott megtakarítások kapcsán ez a mérleg át is billen: többen voltak azok, akik szerint nem jár ilyen megtakarításra állami támogatás, mint azok, akik szerint igen (igen 36,9, nem 37 százalék). A bizonytalanságot jól mutatja, hogy sokan (37,2 százalék) az egyéb megtakarítási tartalommal rendelkező biztosításokhoz is társítottak állami támogatást. A pénzügyi tájékozottság szubjektív mércéje azt mutatja, hogy a válaszadók 29 százaléka helyezte saját ismereteit a „tájékozott” szekcióba (7 százalék kifejezetten 
tájékozott), és hasonló azok aránya, akik nem tartják magukat tájékozottnak (25 százalék). Azaz közel minden második lakos (44,9 százalék) középre helyezi saját pénzügyi ismereteit.

1. ábra: Ön szerint jár-e állami támogatás az alábbi megtakarítási formákra? (százalék) Lakástakarék-pénztár

Nyugdijbiztositás

Állampapir

Megtakaritási tartalommal is rendelkezô biztositás, életbiztosítás

Önkéntes nyugdijpénztár

\begin{tabular}{|r|c|c|c|}
\hline \multicolumn{2}{|c|}{69,2} & 15,0 & 15,8 \\
\hline & & & $|c|$ \\
\hline 43,9 & 24,6 & \multicolumn{2}{|c|}{31,5} \\
\hline 42,8 & 29,4 & 27,8 \\
\hline 37,2 & 34,8 & 28,0 \\
\hline 36,9 & 37,0 & 26,1 \\
\hline
\end{tabular}

口Igen

$\square$ Nem

$\square$ Nem tudja / Nem válaszol

$N=1102$

Forrás: MABISZ-Századvég kutatás 2018

A kutatási eredmények alapján a magyar háztartások három egyenlő részre oszthatók a megtakarítási képességük alapján, ahogy azt a 2. ábra mutatja. Csak minden harmadik válaszadó tud rendszeres időközönként megtakarítani (33,2 százalék), további 34,1 százalék alkalmanként, és ugyanekkora a különösen sérülékeny, megtakarítani nem tudók aránya (32,6 százalék). Ami az életkori különbségeket illeti, a megtakarítani nem tudó lakosok aránya a 18-29 évesek között jóval alacsonyabb, 22 százalék, és a 30-39 évesek között is „csak” 23,8 százalék. ${ }^{5}$

2. ábra: Szoktak Önök megtakarítani a rendszeres jövedelmükböl? (százalék)

\section{$\square$ Igen, rendszeresen \\ Igen, de csak esetenként \\ $\square$ Nem \\ ¿Nem tudja / Nem válaszol}

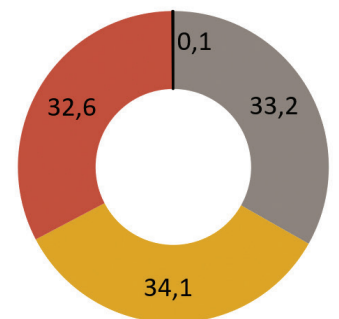

$N=1102$

Forrás: MABISZ-Századvég kutatás 2018

A megtakarítások - egy része legalábbis - a megtakarítani képes válaszadók 40,6 százalékánál folyószámlán van, nem lekötve, 39,7 százalékánál pedig otthon, készpénzben (3. ábra). 35,2 százalék azok aránya, akik tartanak valamekkora összeget kamatozó vagy másféle hozamot biztosító pénzügyi termékben. Azoknak, akik félre tudnak tenni, több mint kétharmada (67,7 százaléka) rövid, maximum ötéves időtávra takarít meg, 29,3 százalék egy évnél is rövidebbre. A 4. ábrán látható azonban, hogy a megtakarítani képes lakosság többsége (52,4 százaléka) figyelembe veszi az állami támogatások meglétét pénzügyi döntései során.

3. ábra: Milyen formában tartja Ön megtakaritásait? (százalék, több válasz is megjelölhető volt)

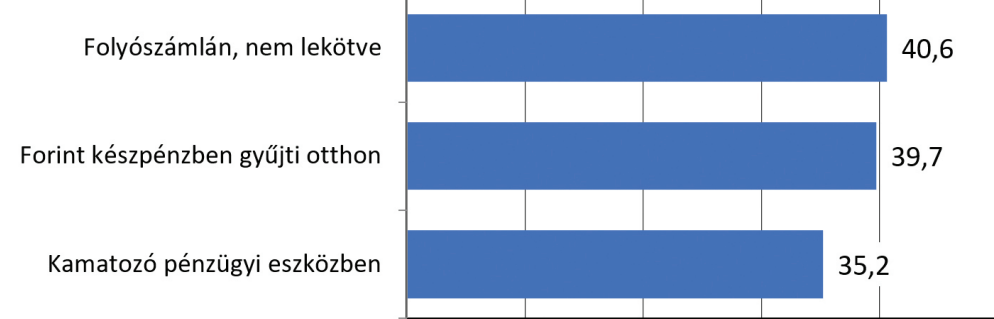

$N=741$, Akik szoktak megtakarítani rendszeres jövedelmükböl

Forrás: MABISZ-Századvég kutatás 2018

4. ábra: Ön pénzïgyi döntéseikor figyelembe szokta-e venni, hogy van-e állami támogatás az egyes megtakarítási formákhoz? (százalék)

\section{$\square$ Igen \\ $\square$ Nem}

- Nem tudja / Nem válaszo

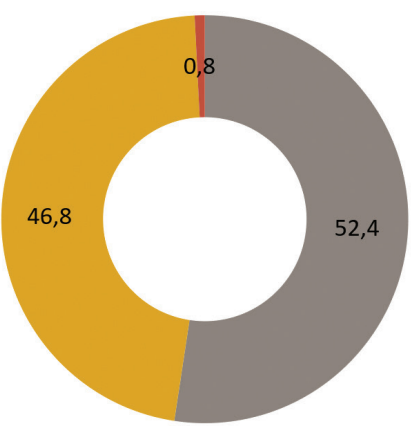

$N=741$, Akik szoktak megtakarítani rendszeres jövedelmükböl

Forrás: MABISZ-Századvég kutatás 2018

A pénzügyi tudatosság egy másik indikátorának használtuk, hogy milyen mértékben váltogatják pénzügyi szolgáltatóikat az ügyfelek, illetve mennyire kísérik figyelemmel az új ajánlatokat. Az adatok azt mutatják, hogy a bankszámlával rendelkezők mindössze 17,8 százaléka váltott bankot az elmúlt öt évben, és nagyon hasonló jellemző a lakásbiztosítási piacra is, ahol 14,8 százalék váltott az elmúlt öt évben (5. ábra). ${ }^{6}$ A 6. ábra mutatja, hogy a banki ügyfelek 12,3 százaléka kíséri figyelemmel más bankok ajánlatait, és vizsgálja felül saját számláját rendszeresen. 34 százalék alkalmanként teszi meg ezeket, az ügyfelek többsége pedig egyáltalán nem 
(53,6 százalék). Ennél rosszabb a helyzet a lakásbiztosítók ügyfeleinél. 60,5 százalékuk nem kíséri figyelemmel az elérhető lakásbiztosítási lehetőségeket, ajánlatokat, és többségük ( 51,5 százalékuk) nem is „tartja karban”7 biztosítását.

5. ábra: Bank-, lakásbiztosító-váltási szokások (százalék)

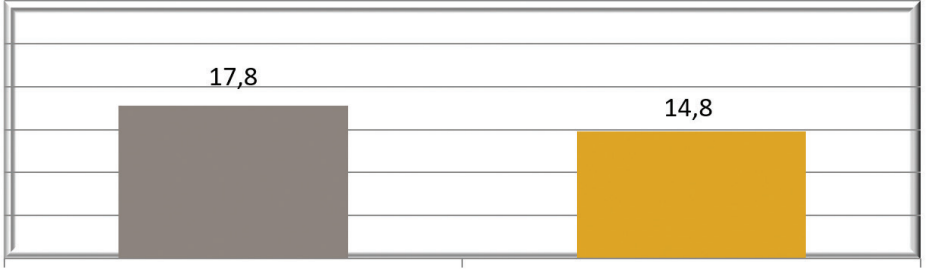

Váltott bankot az elmúlt 5 évben Váltott lakásbiztosítót az elmúlt 5 évben

$N($ bank $)=842$, Akiknek van bankszámlája; $N$ (lakásbiztositó)=832, Akiknek van lakásbiztositója Forrás: MABISZ-Századvég kutatás 2018

6. ábra: Ön figyelemmel kíséri...? (százalék)

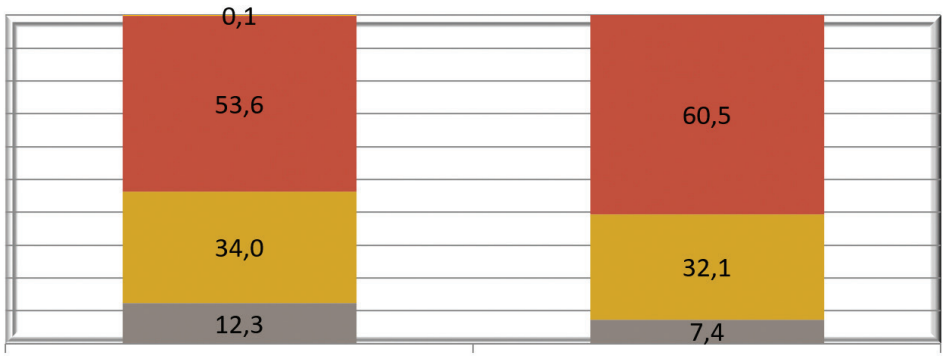

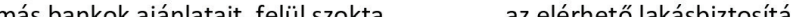

Igen, rendszeresen $\|$ Igen, alkalmanként $\quad$ Nem $\|$ Nem tudja / Nem válaszol

$N($ bank $)=842$, Akiknek van bankszámlája; $N$ (lakásbiztositó)=832, Akiknek van lakásbiztositója Forrás: MABISZ-Századvég kutatás 2018

A biztosítások terén mindazonáltal általános a konszenzus a magyar társadalomban, hogy fontos életünk, egészségünk biztosítása (60,5 százalék teljes mértékben, 27 százalék inkább egyetért ezzel). A kutatási adatok alapján az ügyfelek ráadásul meglehetősen korán belépnek a biztosítási piacra. 17,2 százalékuk már 18 évesen vagy fiatalabb korában megkötötte élete első, nem kötelező biztosítását, további 30,1 százalékuk 19-25 évesen (7. ábra). Azaz a válaszadók közel fele (47,3 százaléka) 25 évesen vagy fiatalabb korában kötötte meg élete első, nem kötelező biztosítását.

7. ábra: Ön hány évesen kötötte első nem kötelező biztosítását? (százalék)

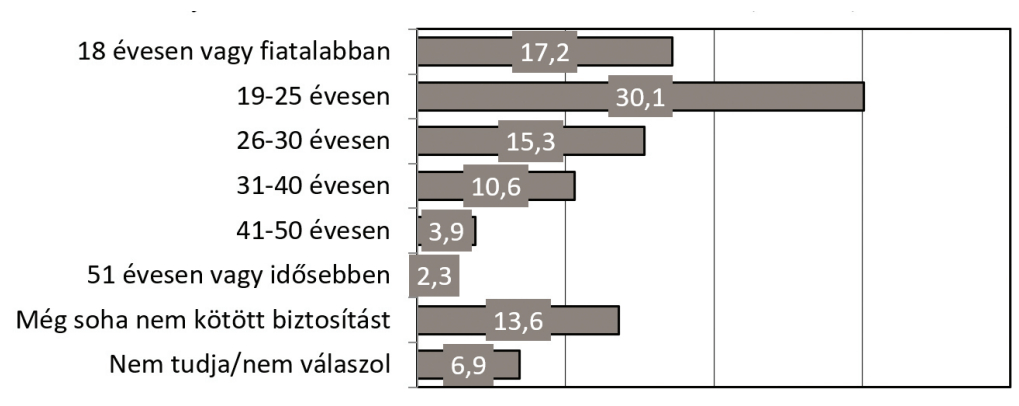

$N=1102$

Forrás: MABISZ-Századvég kutatás 2018

\section{A pénzügyi ismeretek és tudatosság demográfiai háttere}

A pénzügyi ismeretek mögött meghúzódó demográfiai különbségeket többváltozós lineáris regresszió modellel (stepwise) vizsgáltam. A függő változó egy olyan index volt, amely azt mutatta, hogy a válaszadó az egyes megtakarítási termékek közül hány terméknél jelölte meg helyesen, hogy tartozik-e hozzá állami támogatás. Az index minimuma tehát 0 , maximuma 5 volt. A független változók közé tartozott a nem, az életkor, a gazdasági aktívitás, az iskolai végzettség, a településtípus, a szubjektív anyagi helyzet és a havi egy före jutó nettó jövedelem.

A modell magyarázó ereje nem kifejezetten magas (korrigált R2=0,157). Ahogy az 1. táblázat mutatja, három változó, az életkor (Béta $=-0,267)$, az iskolai végzettség $(B e ́ t a=0,212$ ) és a havi nettó jövedelem (Béta $=0,084)$ mutatott szignifikáns lineáris összefüggést az ismeretekkel. Más szóval minél fiatalabb a válaszadó, minél magasabb az iskolai végzettsége, és minél nagyobb jövedelemből gazdálkodnak otthon, annál tájékozottabb a támogatási lehetőségekkel kapcsolatban. Ahogy a béta értékek is mutatják, az életkor hatása volt a legerősebb, és az iskolai végzettség belépése szintén jelentősen emelte a megmagyarázott hányadot. Az is kiderült, hogy a nemnek, a lakóhelynek és a gazdasági aktivitásnak nincs szignifikáns hatása ezekre az ismeretekre. 
1. táblázat: A pénzügyi ismeretekre illesztett többváltozós lineáris regressziós modell

\begin{tabular}{|l|c|c|c|}
\hline & $\beta$ & S.E. & Béta \\
\hline Konstant & 2,333 & 0,169 & \\
\hline Életkor & $\mathbf{- 0 , 0 2 1}$ & $\mathbf{0 , 0 0 2}$ & $\mathbf{- 0 , 2 6 7 * * *}$ \\
\hline $\begin{array}{l}\text { Legmagasabb befejezett iskolai } \\
\text { végzettség }\end{array}$ & $\mathbf{0 , 1 7 8}$ & $\mathbf{0 , 0 2 7}$ & $\mathbf{0 , 2 1 2} * * *$ \\
\hline $\begin{array}{l}\text { Átlagos, egy személyre jutó havi } \\
\text { nettó bevétel, jövedelem }\end{array}$ & $\mathbf{0 , 0 6 9}$ & $\mathbf{0 , 0 2 7}$ & $\mathbf{0 , 0 8 4 ^ { * * }}$ \\
\hline Nem & 0,016 & 0,515 & 0,607 \\
\hline Településtípus & $-0,008$ & $-0,246$ & 0,806 \\
\hline Szubjektív anyagi helyzet & $-0,052$ & $-1,606$ & 0,109 \\
\hline Teljes munkaidöben dolgozik & 0,005 & 0,157 & 0,875 \\
\hline Részmunkaidőben dolgozik & $-0,031$ & $-1,064$ & 0,288 \\
\hline Munkanélküli & 0,026 & 0,899 & 0,369 \\
\hline Tanuló & 0,005 & 0,179 & 0,858 \\
\hline Nyugdíjas & $-0,076$ & $-1,753$ & 0,08 \\
\hline Háztartásbeli & 0,039 & 1,319 & 0,187 \\
\hline
\end{tabular}

Forrás: saját szerkesztés

$\mathrm{R}^{2}=0,16 ; \operatorname{korrR}^{2}=0,157$

Magyarázat: ${ }^{* *} \mathrm{p}<0,001 ;{ }^{* *} \mathrm{p}<0,01 ;{ }^{*} \mathrm{p}<0,05$

Megjegyzés: vastagon szedve a statisztikailag szignifikáns összefüggések $(\mathrm{p}<0,05)$

A pénzügyi tudatosság demográfiai hátterét egy többváltozós bináris logisztikus regresszió modellel vizsgáltam. Függő változóként az Ön figyelemmel kíséri más bankok ajánlatait, felül szokta vizsgálni saját számláját? bináris változóvá alakított változatát használtam (Igen-Nem). A független változók közé ezúttal is a nem, az életkor, a gazdasági aktivitás, az iskolai végzettség, a településtípus, a szubjektív anyagi helyzet és a havi egy före jutó nettó jövedelem tartozott.

A modell magyarázó ereje ezúttal még alacsonyabb volt (Nagelkerke $\left.R^{2}=0,052\right)$. Szignifikáns hatása egyedül a havi nettó egy före jutó jövedelemnek $(\operatorname{Exp}(\beta)=1,16)$ és az iskolai végzettségnek $(\operatorname{Exp}(\beta)=1,13)$ volt $(2$. táblázat). Más demográfiai változó tehát nem hatott szignifikáns mértékben arra, hogy figyelemmel kísérik-e a válaszadók más bankok ajánlatait. Figyelemre méltó, milyen csekély hatása van ezúttal az életkornak.
2. táblázat: A pénzügyi tudatosságra illesztett többváltozós bináris logisztikus regressziós model

\begin{tabular}{|l|c|c|c|}
\hline & $\beta$ & S.E. & $\operatorname{Exp}(\beta)$ \\
\hline Konstant & $-1,194$ & 0,764 & 0,303 \\
\hline Nem & $-0,232$ & 0,165 & 0,793 \\
\hline Életkor & 0 & 0,007 & 1 \\
\hline $\begin{array}{l}\text { Legmagasabb befejezett iskolai } \\
\text { végzettség }\end{array}$ & $\mathbf{0 , 1 2 5}$ & $\mathbf{0 , 0 5 5}$ & $\mathbf{1 , 1 3 3}$ \\
\hline Településtípus & 0,016 & 0,075 & 1,016 \\
\hline Szubjektív anyagi helyzet & 0,058 & 0,093 & 1,06 \\
\hline $\begin{array}{l}\text { Átlagos, egy személyre jutó havi } \\
\text { nettó bevétel, jövedelem }\end{array}$ & $\mathbf{0 , 1 4 9}$ & $\mathbf{0 , 0 5 8}$ & $\mathbf{1 , 1 6 *}$ \\
\hline Teljes munkaidőben dolgozik & $-0,032$ & 0,438 & 0,968 \\
\hline Részmunkaidőben dolgozik & 0,418 & 0,535 & 1,52 \\
\hline Munkanélküli & $-0,501$ & 0,656 & 0,606 \\
\hline Tanuló & $-0,053$ & 0,552 & 0,948 \\
\hline Nyugdíjas & 0,051 & 0,48 & 1,052 \\
\hline Háztartásbeli & 0,982 & 0,558 & 2,669 \\
\hline
\end{tabular}

Forrás: saját szerkesztés

Nagelkerke $\mathrm{R}^{2}=0,052$

Magyarázat: ${ }^{* *} \mathrm{p}<0,001 ;{ }^{* *} \mathrm{p}<0,01 ;{ }^{*} \mathrm{p}<0,05$

Megjegyzés: vastagon szedve a statisztikailag szignifikáns összefüggések $(\mathrm{p}<0,05)$

\section{Következtetések}

Jelen tanulmány egy lakossági közvélemény-kutatás eredményeinek vázolására vállalkozott. Az eredmények a pénzügyi kultúra és tudatosság magyarországi helyzetének megértéséhez szolgálnak adalékul. Az adatok számos ponton alátámasztják az elmúlt években hasonló témában készült felmérések következtetéseit. Kiderült egyrészt, hogy a magyar társadalom mintegy kétharmadának anyagi helyzete lehetővé teszi valamilyen mértékủ megtakarítás felhalmozását, azaz számottevő befektetési potenciál realizálódik a háztartások döntő részében. Másrészt azonban arra is rávilágít a kutatás, hogy ezeket a megtakarításokat nagyon sok esetben továbbra is készpénzben vagy folyószámlán nem lekötve őrzik, és nem valamilyen kamatozó vagy másféle hozamot biztosító pénzügyi termékben, ráadásul több mint kétharmada (67,7 százaléka) azoknak, akik félre tudnak tenni, rövid, maximum ötéves időtávra takarít meg. A tudatosság alacsony szintjét jelzi emellett, hogy sem a banki ügyfelek, sem a lakásbiztosítók ügyfelei nem „járnak nyitott szemmel” a piacon, nem keresnek új ajánlatokat. Más mérésekkel összhangban a pénzügyi tájékozottság terén is komoly lemaradás mutatkozik, a lakosság többsége nincs tisztában az állami támogatások nyújtotta lehetőségekkel. A regressziós modellek tanúsága szerint van valamekkora pozitív hatása az anyagi helyzet javulásának és az iskolai végzettség emelkedésének, 
illetve az állami támogatások ismertsége esetén az életkornak; ezt leszámítva azonban minden társadalmi csoportra igazak a fenti megállapítások. ${ }^{9}$ Bizakodásra adhat okot, hogy a fiatalabb korosztályok megtakarítási képessége jóval nagyobb, és hogy az egyének közel fele (47,3 százaléka) 25 évesen vagy fiatalabb korában belép a biztosítási piacra, és megköti élete első, nem kötelező biztosítását.

Jelen eredmények alátámasztják a pénzügyi tudatosság fejlesztését célzó törekvések indokoltságát. Jó hír a pénzügyi tudatosságot fejlesztő nemzeti stratégia megszületése, és sok olyan kezdeményezésre van szükség, mint a Pénziránytű Alapítvány által szervezett csatlakozás az Európai Pénzhéthez vagy a MABISZ Fiatal Generációs Stratégiája. Kétségkívül a fiatal generációk ismereteinek és szemléletformálásának ösztönzése a legfontosabb. Mindazonáltal osztom azok véleményét, akik szerint a pénzügyi kultúrát nem pusztán a gazdasági attitűdök és ismeretek összességének kell tekinteni, hanem a tágabb értelemben vett kultúra, az értékek, a gondolkodási és viselkedési minták, berögződések összefüggésében is kell értelmezni (Bárczi-Zéman, 2015). Ez fontos következményekkel jár a pénzügyi kultúra fejlesztésének praktikus oldalára nézve. Ahogy Kovács Péter fogalmaz, „a fejlesztő tevékenységek nemcsak a pénzügyi ismeretekre kell, hogy koncentráljanak, hanem a gyakorlatiasság mellett attitűdöt, hozzáállást is fejleszteni kell” (Kovács P., 2017, 36.), a tapasztalatok ugyanis azt mutatják, hogy a gazdasági ismeretek oktatása nem feltétlenül eredményez magas pénzügyi tudatosságot (Luksander és mtsai., 2014.). Más szóval a pénzügyi kultúra fejlesztéséhez a különböző területek összefogására és multidiszciplináris megközelítésre van szükség.

\section{HIVATKOZÁSOK}

'Az angolban financial literacy. A pénzügyi kultúrának számos értelmezése és definíciója létezik. Jelen tanulmány ezek részletes ismertetésére nem vállalkozik. Magyarországon a Nemzeti Bank dolgozott ki elsőként átfogó definíciót: „A pénzügyi ismeretek és készségek olyan szintje, amelynek segítségével a zegyének képesek a tudatos és körü̈ltekintő döntéseikhez szükséges alapvetö pénzügyi információkat azonosítani, majd azok megszerzése után azokat értelmezni, és ez alapján döntést hozni, felmérve döntésük lehetséges jövőbeni pénzügyi, illetve egyéb következményeit.”' (MNB, 2008).

2Forrás: a Századvég Alapítvány és a MABISZ közös közvélemény-kutatásai

${ }^{3} \mathrm{~A}$ minta demográfiai összetétele megtekinthető az 1. sz. mellékletben.

"A lekérdezés idején még járt állami támogatás a lakástakarék-pénztárakr.

${ }^{5} \mathrm{~A}$ további demográfiai különbségekre később részletesen kitérek.

'Más kérdés, hogy az adatok alapján ennek fö oka, hogy az ügyfelek elégedettek lakassbiztosítójukkal.

Nem jelenti be lakásbiztositójának, ha az ingatlanának és ingóságainak értéke változik.

${ }^{8} \mathrm{~A}$ nem dummy valtozokent lepett be a modellbe, a szinten nominalis mérési szintủ gazdasági aktivitás változónál pedig

'Érdekes, hogy szemben például Luksander és munkatársai (2014) ered ményeivel, kevés szignifikáns eredményt találtunk.

\section{IRODALOMJEGYZÉK}

Atkinson, A. - Messy, F. (2012): Measuring Financial Literacy: Results of the OECD / International Network on Financial Atkinson, A. - Messy, F. (2012): Measuring Financial eriteracting on Finance, Insurance and Private Pensions, No. 15, OECD Publishing DOI: https://doi.org/10.1787/5k9csfs90fr4-en

Banai, A - Kolozsi, P. P. (2018): Fenntartható hitelpiac, fenntartható fejlö́dés = Sustainable lending, sustainable development. Koz-gazdasag, 13 (2). pp. 135-143. DO1. https://doi.org/10.1426/RETP2018.02.07

Bárczi, J. - Zèman, Z. (2015): A pénzügyi kultúra és annak anomáliái, Polgári Szemle, 11(1-3) pp. 72-80.

. Hornyák, A. (2013): Pénzügyi kultúra és gazdasági oktatás. Ez lehet a megoldás? Educatio. 22. évf. 1. sz. pp. 89-95. Huzdik, K. - Béres, D. - Németh, E. (2014): Pénzügyi kultúra versus kockázatvállalás empirikus vizsgálata a felsőoktatásban tanuloknal. Penzugyi Szemle, (4) pp. 476-484

A. (2012): Financial literacy and the financial crisis. The World Bank. https://doi.

. Kovács, P. (2017): Fiatalok pénzügyi kultúra mérésének, fejilesztésének lehetőségei. In: Pál Zs.(szerk.): A pénzügyi kultúra aktuális kérdései, különös tekintettel a banki szolgáltatásokra. A közgazdaságtani-módszertani képzés fejlesztéséért Alapítvány, Miskolc, pp. 31-37.

E. (2014): A felsőotatásban tanuló fiatalok pénzügyi kultúráját befozügyi Szemle, 2014/2, pp. 237-258.

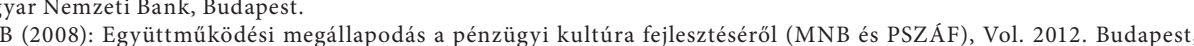
MNB (2008):
MNB, PSZAF

MNB (2017): Pénzügyi Stabilitási Jelentés, 2017. május.

Nemeth, E. - Beres, D. - Huzdik, K. (2015): The Attitude of Young Hungarian Adults to Loans, Journal of Business and Social Németh, E. (2017). Pénzügyi kultúrát fejlesztổ képzések: felmérés és diagnózis. Ú PEDAGOGIAI SZEMLE, 67(7-8). pp. 46-69. Vaskövi, Á. (2018): Pénzügyi tudatosság és hosszabbodó nyugdíjas évek. Beszámoló az idei nemzetközi aktuárius kongresszusról (Berlin, 2018. Június). Biztositás és Kockázat, 5(3), pp. 48-57. http://dx.doi.org/1018530/BK.2018.3.48 Zsótér, B. - Németh, E. - Luksander, A. (2017): A társadalmi-gazdasági környezet változásának hatása a pénzügyi kultúrára.

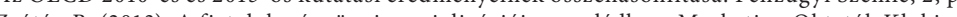

Budapest, 2013. 


\section{MELLÉKLET}

1. melléklet: A minta összetétele a fontosabb demográfiai változók mentén

\begin{tabular}{|l|c|}
\hline & $\%$ \\
\hline Férfi & 46,6 \\
\hline Nö & 53,4 \\
\hline $18-29$ éves & 18,1 \\
\hline $30-39$ éves & 19,4 \\
\hline $40-49$ éves & 16,2 \\
\hline $50-59$ éves & 17,6 \\
\hline $60+$ éves & 28,7 \\
\hline Nyolc általános vagy alacsonyabb & 28,9 \\
\hline Szakiskola vagy szakmunkásképző & 22,2 \\
\hline Középiskolai érettségi & 31,3 \\
\hline Főiskolai vagy egyetemi diploma & 17,6 \\
\hline 50.000 forint alatti egy före jutó havi nettó jövedelem & 16,8 \\
\hline 50.001 - 75.000 Ft & 16,2 \\
\hline 75.001 - 100.000 Ft & 22,6 \\
\hline 100.000 Ft felett & 37 \\
\hline Nem tudja/nem válaszol & 7,5 \\
\hline Rossz & 11,3 \\
\hline Közepes & 24,6 \\
\hline Jó & 63,6 \\
\hline Nem tudja/nem válaszol & 0,5 \\
\hline Budapest & 18,1 \\
\hline Megyeszékhely & 17,9 \\
\hline Város & $-1,194$ \\
\hline Község & 63,6 \\
\hline Kelet-Magyarország & 37,9 \\
\hline Közép-Magyarország & 35,3 \\
\hline Nyugat-Magyarország & 26,9 \\
\hline Teljes munkaidöben dolgozik & 50,1 \\
\hline Részmunkaidöben dolgozik & 4,7 \\
\hline Munkanélküli, szociális segélyezett & 4 \\
\hline Tanuló & 5,2 \\
\hline Nyugdíjas & 26,7 \\
\hline Háztartásbeli, gyermekgondozási ellátást kap & 5,1 \\
\hline Egyéb & 4,2 \\
\hline & \\
\hline
\end{tabular}

